\title{
FIGURES OF TRANSCENDENCE IN WHITMAN'S POETRY
}

\section{Carmine SarRacino}

\author{
Make no puns \\ funny remarks \\ Double entendres \\ "witty" remarks \\ ironies \\ Sarcasms \\ Only that which \\ is simply earnest \\ meant,-harmless \\ to any one's feelings \\ - unadorned \\ unvarnished \\ nothing to \\ excite a \\ laugh \\ silence \\ silence \\ silence \\ silence \\ laconic \\ taciturn. ${ }^{1}$
}

PERHAPS ONE OF THE ODDEST features of "Song of Myself" is that this apparent formula for blandness, scribbled in a notebook, produced instead one of the most compelling and controversial poems in American literature. The poem does excite a laugh, and was not harmless to the feelings of such as Whittier, who threw his complimentary copy of Leaves of Grass into the fire. But as we look over Whitman's list we see that the poem succeeds not because Whitman abandoned or violated these tenets; it succeeds even though he remained remarkably true to them.

Whitman repeated four times the quality he wanted to communicate more than any other: silence. Here we find ourselves with no mere oddity, but with an apparent impossibility. Silence cannot be communicated by language, since to talk or to listen or to read is to destroy silence, to shift attention from the thing pointed at-silence-to the finger pointing-the poem. How could Whitman hope to resolve this paradox? How could silence sing? The more fundamental question is: Why would he draw up such a strange list of tenets anyway? Why should silence preoccupy a singer?

These questions go to the heart of the creative process Whitman experienced as a poet, and more, to the heart of the so-called mystical experience that recurred throughout his life, the great secret he repeatedly hinted about 
in his poetry, especially "Song of Myself." Although "ineffability" is the byword of mysticism, Whitman's mystical experiences need not be banished, as they largely have been, to critically inaccessible realms. To do so is a loss to Whitman readers and scholars. Yet most attempts at explication have resulted in the substitution of one set of ambiguous terms for another. Little is cleared up by defining "cosmic consciousness" as ". . . the consciousness of the self that is the cosmos, the one that is the all, the atman, the internal principle which is also the mighty universal Brahman."

If Whitman did experience higher states of consciousness, can we talk about it critically? For example, do these states have an analyzable structure? If so, does the structure of a higher state of consciousness in some describable way influence the structure of what is created from that level of consciousness, in Whitman's case, his poetry? The answers I will propose shed some light on the odd list of tenets Whitman drew up in his notebooks, and also suggest a solution to the impasse of his apparently contrary impulses for song and for silence.

This approach might seem naive, since I implicitly accept the possibility that Whitman was what he seemed, and that his "mystical experiences" were neither invented nor pretended, nor misunderstood bouts of epilepsy. In 1980s America, dominated as it is by a celebrity culture, by advertising "images," we regard Whitman as a poseur, or an artist who fabricated an image to match his poetic voice. Two recent biographies, Justin Kaplan's Walt Whitman: A Life, and Paul Zweig's Walt Whitman, the Making of the Poet take this approach. Thus what friends regarded as Whitman's Christlike self-sacrifice in the army hospital wards becomes sublimated homosexuality; his countenance of Buddhalike tranquility, a mask. Mrs. Gilchrist, R. M. Bucke, Horace Traubel, and others who revered Whitman we dismiss as "overheated minds," "true believers" who gullibly bought the whole show. Whitman was a bit of a phony, a troubled man, a careerist -in short, a lot like us.

Another motivation for this somewhat cynical portrayal of Whitman stems from our desire to rescue him from the curse of "the good gray poet." Our belief in the redeeming value of evil was noted recently in a review of a biography of Strindberg:

Since Delacroix's day, we have lived under the sign of one of his immediate successors, Arthur Rimbaud, who wrote that the poet, albeit a sage, was the great Sick Man, the great Criminal, the great Accursed. This conception, for a while startling, is by now a received idea. By the standards of the modern man on the street, a Dylan Thomas is obviously a poet while a William Carlos Williams is not. To justify his men or women, the biographer has to go back to the detail of their lives and discover the sinister, or at least the scandalous, element. Ruskin, who has seemed one's primmest uncle, is brought back-vindicated-as a child molester. ${ }^{3}$

So, although Whitman repeatedly reminds himself in notebooks and journals to be plain and simple, to be non-literary, Zweig, for example, sees this intention as a kind of gimmick, like the novelist's pose of "telling the facts." Zweig 
concludes, with a distinctly contemporary paranoiac knowingness, that Whitman's bag of tricks is deep. Alternatively, I hope that an understanding of Whitman's experiences of expanded awareness will shed light on his desire for simplicity, and at the same time disclose the depth and profundity of these experiences.

A stock criticism of Whitman, his supposed lack of artistic polish, refinement of craft, and subtlety, stems directly from the mistreatment of the writing born of Whitman's expanded awareness. From Henry James on he has often disappointed the educated reader looking for the literary. In the list I have cited from his notebooks, he casts down most of the conventional techniques of modern literature, irony foremost among them. This does not, however, leave him without subtlety. Intuitively aware of the heuristic inadequacies of language on the level of meaning, Whitman shifted his attention to what his poem could reveal, not state outright. "Have you felt so proud," he asks with some forbidden sarcasm in section two of "Song of Myself," "to get at the meaning of poems?" What he promises in the next line is not meaning, but direct conveyance to "the origin of all poems," which for Whitman was the "mystical experience" of a fourth major state of consciousness, transcendental consciousness, a state of complete mental quietude, silence. We might recall another famous mystic, Gautama the Buddha, who when pressed to sermonize about his enlightenment remained silent and held up a flower. In an actual, nonsentimental sense, "Song of Myself" was the flower Whitman held up for those with eyes to see. In this way alone could he fulfill his promise in the "Preface" to the 1855 edition of Leaves of Grass to ". . . well nigh express the inexpressible."

Efforts to illuminate Whitman's mysticism have often failed because critics have taken classically hermeneutical approaches to this poet who insists that argument is futile and that only our presence itself convinces. In section twenty-five of "Song of Myself": "Writing and talk do not prove me, I I carry the plenum of proof and every thing else in my face, / With the hush of my lips I wholly confound the skeptic" (italics mine). For this reason Whitman went to extremes to make his presence visible in Leaves of Grass, to "show his face" not only by composing the poems, but then by incorporating those poems, that "soul" of his mind's creation, in a physical artifact, a body crafted with his hands. In an almost literal sense, Whitman tried to make his book a physiological extension of himself. He chose the paper and the typeface, set some of the type, printed and bound the pages, designed the unusual covers, and even included an engraving from a photograph of himself. Anyone can speculate about enlightenment. But the enlightened embody enlightenment. It is only necessary that they clearly show themselves, "hold themselves up" to the world, and with the hush of their lips convince or confound.

Whitman wanted his readers to respond to his book as they would respond to his actual presence. His book would contain the structure of his higher state of consciousness embodied in the structure of the poems them- 
selves, in their "face," as it was in his own face. With Whitman, such encoding was not a deliberate technique but an inevitability, in much the way Frost describes how a poem comments on its creation by its very unfolding. "How can a poem have 'wildness' and at the same time a subject that should be fulfilled?" Frost asks. "It should be the pleasure of the poem itself to tell us how it can." This self-commenting quality of a poem he termed "the figure a poem makes."4 John Burroughs, in his biography of Whitman, makes a similar point: " 'Leaves of Grass' requires a large perspective; you must not get your face too near the book. ... Looked at too closely, it often seems incoherent and meaningless; draw off a little and let the figure come out."5

It should be possible for us to see in the figures of poems in Leaves a kind of self-commentary on the structure of the higher state of consciousness that produced them, and that they embody. For the sake of clarity, I will first offer a model of consciousness based on those textbooks of higher states of consciousness, the Vedas, and then look at two main figures that emerge from "Song of Myself" and "A Song of the Rolling Earth" in light of this modelthe circle and the broken line. ${ }^{6}$

Let me begin by explaining transcendental consciousness. Whitman repeatedly alludes to this state of silent inner-wakefulness (often termed "samadhi"), calling it "the mere fact consciousness" or "interior consciousness," as in this excerpt from "Democratic Vistas":

I should say, indeed, that only in the perfect uncontamination and solitariness of individuality may the spirituality of religion positively come forth at all. Only here, and on such terms, the meditation, the devout ecstasy, the soaring flight. Only here, communion with the mysteries, the eternal problems, whence? whither? Alone, and identity, and the mood-and the soul emerges, and all statements, churches, sermons, melt away like vapors. Alone, and silent thought and awe, and aspiration-and then the interior consciousness, like a hitherto unseen inscription, in magic ink, beams out its wondrous lines to the sense. Bibles may convey, and priests expound, but it is exclusively for the noiseless operation of one's isolated Self, to enter the pure ether of veneration, reach the divine levels, and commune with the unutterable.

The Manduka Upanishad recognizes the three usual states of consciousness (waking, sleeping, and dreaming) but adds to these a fourth state of union with the Absolute of Self. This additional state, which Whitman calls "interior consciousness," is termed "transcendental consciousness," or "pure consciousness."7

Usually when we are conscious, our consciousness has an object: we are conscious of some thing-a scene before our eyes, the sound of the wind, a thought, perhaps only a sensation. This consciousness is always limited, bounded by a finite object. For expedience, let us refer to this as the "conscious of $x$ " model, where " $x$ " is any object of consciousness. On the other hand, pure consciousness may be understood as consciousness without an object of consciousness: consciousness simply left alone by itself, undisturbed, silent. With no object to limit it, such consciousness is boundless, infinite.

But how can consciousness alone ever be known? Who, after all, would 
know it? The Upanishads themselves anticipate and frame just such questions: How can the eye see itself? How can the sword cut itself? By whom shall the knower be known?8 The answer must lie in the notion of transcending, an answer Whitman expressed by means of a figure emblematic of transcendence: the circle. In transcendence, the linear "conscious of $x$ " model of awareness simply does not apply. The usual "knower-knowing-known" distinctions dissolve. The Upanishads speak of meditation as a technique to turn the attention exclusively upon a mental object (a mantra) which is then systematically refined until it disappears altogether. At that point of transcendence, there would be awareness - one would not have blacked out-but awareness of what? If these conditions are allowed to be at least theoretically possible, then we have to say that the experiencer is experiencing himself"the noiseless operation of one's isolated self"-as the object of experience. The knower is knowing himself in the act of knowing. The three distinctions-experiencer, experiencing, object of experience-merge into a transcendent unity which the Upanishads call pure consciousness.

The figure most clearly emblematic of the mechanics of transcendence is the circle. Awareness in this fourth state of consciousness, instead of moving outward in a linear direction to become lost in the object, loops back upon itself; it becomes aware of itself. This figure of the circle is repeated throughout "Song of Myself" and other poems as well. It is one of the two principal figures of transcendence in Whitman's poetry; the other is the broken line.

In the very first line "Song of Myself" projects an image of consciousness looping back on itself. "I" is the first word of this poem of the Self. "Celebrate" seems to draw consciousness outward in a linear way, but the final word bends the arc of consciousness back to its starting point: "myself." In this first line, then, we have the three components of ordinary waking-state awareness: experiencer (I), act of experiencing (celebrate) and object of experience (myself). The circle, however, fuses these separate components into a transcendent unity. If we read the line as Whitman revised it after 1855, allowing for the initial ellipsis we simply add another circle, “. . . and sing myself. ...."

For many reasons, to call Whitman the poet of transcendent unity is no exaggeration. In the next line of the opening, for instance, he extends unity to the most immediate "other," the reader: "And what I assume you shall assume..." The last word of the poem, in fact, is "you." By the time that last word occurs, however, the identity of the first word (I) and the last (you) should be established, unified within the transcendent Self. Thus the poem ends at its beginning point, describing a circle.

The fifth section of the poem deals most precisely with the actual experience of transcendence. The whole section is addressed to his "soul"-his essence, his consciousness - and he says: "I mind how once we lay such a transparent summer morning,/How you settled your head athwart my hips and gently turn'd over upon me. ..." Again, we have an image of a turning 
back upon oneself, a circle, for his soul "turns over" upon him, turns inward in an experience of union rendered in sexual terms. ${ }^{9}$

Whitman's union, though, is of his self and his Self, the two selves, he tells us in a notebook entry, he had always been curiously aware of. The one self is factlike, limited, closed, comprised of specifics such as his six-foot height, his two-hundred-pound weight, his rosy complexion, his age and personal history. The other self, or Self as he often wrote it, could not be contained between his hat and bootsoles, but was a "kosmos," unbounded. $\mathrm{He}$ develops these two senses of selfhood very clearly in section four of "Song of Myself."

From the point of view of unboundedness, the bounded-any ordinary object of perception, including one's facticial self (to borrow a term from Sartre)-can appear "other." So section five begins: "I believe in you my soul, the other I am must not abase itself to you...." In the experience that follows Whitman realizes experientially the identity of the bounded with the unbounded. The bounded, Whitman's physical nervous system, like a lover "contains" the unbounded, his consciousness: “... And parted the shirt from my bosom-bone, and plunged your tongue to my bare-stript heart, / And reach'd till you felt my beard, and reach'd till you held my feet."

The reality of blissful transcendent union of the bounded with the unbounded is Whitman's closing revelation in section five: "Swiftly arose and spread around me the peace and knowledge that pass all the argument of the earth. ..." The images that follow hint of the identity of the infinite and the finite: ". . . the hand of God is the promise of my own, / . . all the men ever born are also my brothers...." And the adjective modifying the final catalog of concrete, obviously bound objects - ". . . leaves stiff or drooping in the fields, / And brown ants . . / And mossy scabs . . . heap'd stones. ..."-is "limitless."

On the largest scale of its progressive unfolding also "Song of Myself" describes the figure of a circle, emblematic of the self-referential aspect of transcendence. We follow Whitman on a walk without destination, very much an Emersonian journey of the kind described in his essay "Circles" when he quotes Cromwell: "A man ... never rises so high as when he knows not whither he is going." A loose definition of transcendence could be "selfforgetting," since the self is completely absorbed into the Self and is in a sense lost or abandoned. This may be part of Emerson's meaning when he says in the same essay, "The way of life is wonderful; it is by abandonment." When we "walk" this way, rather than feeling lost, we enjoy a sense of discovery. We find our Self everywhere. So Whitman, in a walk so free of self he deleted his name from the cover and title page of the first edition of Leaves of Grass, finds his Self everywhere ("every atom belonging to me as good belongs to you"). If he (and we) do not know where he is going, it is because really there is nowhere to go. The Upanishads say repeatedly "I am That" (unbounded pure consciousness), "Thou are That and all this is nothing but That." So 
Whitman closes his song, ". . missing me one place, search another. . ." The poem begins in the Self, returns repeatedly to the Self, and at the end comes around again to the Self, a circle of circles. The final line is a last hint-one of Whitman's favorite words - that his experience of unbounded Selfhood is not eccentric, but universal. We should be interested in his song, for it is our song too, even if we are not yet its singers. In the first section he told us that what he assumed, we too should assume. In the last section he promises that we too will one day discover the unbounded Self: "I stop somewhere waiting for you." 10

Let us consider briefly a second figure of transcendence in Whitman's work, the infinite broken line. This figure emerges most clearly from Whitman's catalog technique and can be connected with the structure of the higher state of consciousness beyond transcendental consciousness: complete enlightenment, called in Vedic literature "all-time samadhi" or "samadhi without any seeds of ignorance" (nirbija samadhi). From R. M. Bucke onward, Whitman critics have favored the term "cosmic consciousness." In cosmic consciousness the silent, unbounded awareness of transcendental consciousness is never lost. In activity, it coexists with the bounded consciousness of specific thoughts, feelings, perceptions. Manduka Upanishad explains: "Like two birds of golden plumage, inseparable companions, the individual self and the immortal Self are perched on the branches of the selfsame tree." The individual self is active; the unbounded self is silent. "The former tastes of the sweet and bitter fruits of the tree; the latter, tasting of neither, calmly observes." 11 Whitman wrote in his notebook, "I cannot understand the mystery: but I am always conscious of myself as two (as my soul and I)." 12 And throughout his poetry he uses the term "witness" to describe the curiously involved yet detached experience, "both in and out of the game" as he says in section four of "Song of Myself."

The catalog is an apt representation of the coexistence of pure consciousness along with thoughts, perceptions, and feelings, for it embodies the opposite and irreconcilable qualities of infinity and limitation. The catalog is composed of concrete objects, perceptions, and recollections; but the first item is simply the one Whitman has begun with, not a predictable or required starting point, and the last item does not exhaust the possibilities or reach a necessary conclusion. As Paul Zweig has observed, "A random list is, by definition, merely a sample of an unspoken list containing everything." 13 The catalog conveys the feeling of infinite extension preceding its beginning and following its ending. We might say that the catalog is finite in its elemental composition but infinite in its structure, and so combines without damage the irreconcilable opposites of Whitman's experience of cosmic consciousness: mortal body, and immortal soul; finite matter, and unbounded consciousness.

In another way, too, the catalog embodies the duality of the bounded versus the unbounded, or of the outer reality versus the inner. Not only does the 
catalog strike us as a segment lifted from an infinite sequence, but infinity is also interfused among elements. Because items in the catalog do not follow one another in any logical or even predictable sequence, the gaps between elements are not mere pauses, nor are they emptiness, but rather silences of all possibilities. Consider these excerpts from section fifteen of "Song of Myself":

The pure contralto sings in the organ loft,

The carpenter dresses his plank, the tongue of his foreplane whistles its wild ascending lisp,

The married and unmarried children ride home to their Thanksgiving dinner,

The pilot seizes the king-pin, he heaves down with a strong arm,

The mate stands braced in the whale-boat, lance and harpoon are ready....

And a bit later:

The crew of the fish-smack pack repeated layers of halibut in the hold,

The Missourian crosses the plains toting his wares and his cattle,

As the fare-collector goes through the train he gives notice by the jingling of loose change. ...

We don't know what might emerge. Anything might. Each gap in a sense contains infinity, an immense richness of limitless possibility, while each item is concrete, specific, bounded. The unfolding of the catalog, then, expresses Whitman's total reality of coexistent boundaries along with unboundedness, a fifth state of consciousness which yokes (a word derived from the Sanskrit yoga) the ordinary waking state and the fourth state of transcendental consciousness. Just as Whitman is "both in and out of the game," so the catalog is both busy and, at the same time, silent.

Although "Song of Myself" is filled with insights and flashes of revelation, "Song of the Rolling Earth" ventures beyond hints and moves in the direction of explication. Whitman begins by announcing a language of nature, a language of perfection and silence: "Were you thinking that those were the words, those upright lines? Those curves, angles, dots? / No, those are not the words, the substantial words are in the ground and sea, / They are in the air, they are in you." Here we have the beginning of a philosophical rationale for why "our presence alone convinces." As he states a few lines later, "Human bodies are words...." Our physical presence, then, is an undisguised statement. By extension, all forms of earth and sea are similarly full and true statements, so that the mere physical fact of "the rolling earth" becomes itself a complete song.

Whitman's ability to read this truest language, these hieroglyphs of the unmanifest manifesting, underlies his fascination with faces, each of which spoke to him of a complete personality or a personal history, as is most evi- 
dent in his poem "Faces." Indeed, he often requested photographs from friends he could not otherwise see, as in a letter to Tennyson of 27 April 1872 when he repeats an earlier request for a photograph and ends with the admonition, "Don't forget the picture."14 There is no evidence Whitman knew the famous story of the Buddha's silent sermon, but he says in the third verse of the first section of "Song of the Rolling Earth," "The masters know the earth's words and use them more than audible words."

As the title of the poem suggests, "Song of the Rolling Earth" also is built upon the figure of the circle, the round earth orbiting amid other spheres. The end of the first section elaborates the self-referential figure, placing circles within circles as Whitman had done in "Song of Myself." Amid "centripetal and centrifugal sisters" the "beautiful sister," earth, dances on. In the next verse, however, she is at rest, she "sits undisturbed," so that her motion, her dance, is relative only. Within herself she is quiet, holding in her hand "what has the character of a mirror," the moon. Again the figure here is selfreferential, arching back upon itself as she sits "Holding a mirror day and night tirelessly before her own face." She is, we might say, both in and out of the dance.

The remaining lines of the first section present further cycles: the twenty-four hours of each day, the three hundred sixty-five days of each year. The final ten lines of this section bolster circularity auditorially. "Embracing," itself circular, is repeated three times in two lines. Internal rhyme ". . . the soul's realization and determination ..." and the repeated "ing" sound of the present participle echo in the reader's ear. The simple present emerges, steady and silent amid a whirlwind, in the last line: "The divine ship sails the divine sea."

The second section begins to apply the metaphysical truths and the implied truths of section one to the individual: “... the song is to the singer, and comes back most to him, / The teaching is to the teacher, and comes back most to him, / The murder is to the murderer, and comes back most to him. ..." Growth, development, the soul's journey, are circular, not only in the poetic sense of the soul's journey around the divine sea of the Self, but in an immediate ethical sense: our actions come back to us. We feed upon our own actions and are thereby nourished or poisoned: "... the gift is to the giver, and comes back most to him-it cannot fail...." The final line opens out the implications of this view: "And no man understands any greatness or goodness but his own, or the indication of his own." Whitman will follow this thought to its furthest application in section three.

Whosoever is complete, to him or her "the earth shall surely be complete." Whose consciousness is linear, partial, bounded, for him or her the earth remains "jagged and broken." Through his experiences of transcendence Whitman connects this state of wholeness of awareness with silence, not an empty and dead silence but a lively and expanded silence of all possibilities. The sweetest love, then, is the wholeness of ". . . that which 
contains itself, which never invites and never refuses." And the poem concludes with praise of silence: "I swear I will never henceforth have to do with the faith that tells the best, / I will have to do only with that faith that leaves the best untold."

Whitman would labor to extend his presence to every aspect of his book itself and thereby transform it into a living natural object, an expression, as his body was an expression, of his boundless, silent soul. He tells us in "So Long!" "Camerado, this is no book, / Who touches this touches a man...." As the form of his face inevitably expressed the wholeness of his being, he would trust that the figures, not the words of his poems, would similarly, in their own perfect and silent natural language, "express the inexpressible." If he could avoid the literary, could disdain the conventional, and simply extend himself into his creation, silence would speak, would sing. The song would be of himself.

\section{Elizabethtown College}

\section{NOTES}

1 Walt Whitman, An 1855-56 Notebook Toward the Second Edition of "Leaves of Grass," ed. Harold W. Blodgett (Carbondale: University of Illinois Press, 1959), 7-8.

2 Many of Whitman's contemporaries and friends attempted explication, especially Edward Carpenter and R. M. Bucke, both of whom were familiar with Vedic literature. William James dealt with Whitman's mysticism in The Varieties of Religious Experience, and in our own day there are several noteworthy studies: James E. Miller, “'Song of Myself' as Inverted Mystical Experience" in A Critical Guide to Leaves of Grass (Chicago: University of Chicago Press, 1957), 6-35; and more generally, Arthur Christy, The Orient in American Transcendentalism (New York: Columbia University Press, 1932). V. K. Chari, whose definition of "cosmic consciousness" I have quoted, has done the most thorough, systematic study in Whitman in the Light of Vedantic Mysticism (Lincoln: University of Nebraska Press, 1965). Chari's definition (p. 34) is inadequate, but his work remains an invaluable source.

3 Eric Bentley, "Sweden's Nasty, Sexist, Racist Genius," New York Times Book Review, 1 September 1985.

4 Robert Frost, "The Figure a Poem Makes," in Complete Poems of Robert Frost (New York: Holt, Rinehart and Winston, 1949).

5 John Burroughs, Whitman: A Study (New York: William H. Wise and Co., 1924), 124.

6 The Vedas are immense and the richas, verses, sometimes impenetrably abstruse. Rig Veda alone contains more than ten thousand verses and is only one of four principal Vedas, to which we must add other lengthy works not technically part of the Vedas, but included in the broad category of "Vedic literature," such as the Upanishads and the Bhagavad-Gita. I must here acknowledge my indebtedness to Maharishi Mahesh Yogi for his formulation of "Vedic Science," a systematized and rationally comprehensible presentation of Vedic knowledge based upon the fourth major state of consciousness, transcendental consciousness.

I should also point out that a great deal of empirical evidence exists for this fourth state of consciousness. Of the scores of published experiments, I might mention Wallace and Benson's 
"The Physiology of Meditation," Scientific American, 226 (1972) 84-90; also by Wallace et al., “A Wakeful Hypometabolic State," American fournal of Physiology, 221 (1971), 795-799.

7 "The life of man is divided between waking, dreaming, and dreamless sleep. But transcending these three states is superconscious vision-called the Fourth." The Upanishads, trans. by Swami Prabhavananda and Frederick Manchester (California: Mentor Classics, 1948), 49. All other references to the Upanishads are from this edition. The quotation from "Democratic Vistas" is in Floyd Stovall, ed., Prose Works 1892 (New York: New York University Press, 1964), 2:398-399.

8 The Brihadaranyaka Upanishad says: "As long as there is duality, one sees the other, one hears the other, one smells the other, one speaks to the other; but when for the illumined soul the all is dissolved in the Self, who is there to be seen by whom, who is there to be smelt by whom, who is there to be spoken to by whom, who is there to be thought of by whom, who is there to be known by whom?" (Upanishads, 89).

9 The amorous image of section five was startling to many of Whitman's contemporaries and remains at least puzzling to modern readers. But the experience of the fourth state of consciousness, the Upanishads emphasize, is ananda, surpassing pleasure-bliss. What better concrete metaphor, then, for complete and blissful union than love play? There is, of course, in both Western and Eastern literature a long tradition of sexual religious poetry, especially in the work of Kabir, Mirabai, Rumi, St. John of the Cross, and John Donne, to name a few.

10 On this level of universal Self Whitman makes a similar appointment - to "meet" a prostitute, in "To a Common Prostitute," perhaps the most misread of his poems.

11 Upanishads, 46-47.

12 Walt Whitman, The Uncollected Poetry and Prose of Walt Whitman, ed. Emory Holloway (Garden City, New York: Doubleday, 1921), 66.

13 Paul Zweig, Walt Whitman, The Making of the Poet (New York: Basic Books, 1984), 248249.

14 Walt Whitman, The Correspondence, ed. Edwin Haviland Miller (New York: New York University Press, 1964), 3:174-175. 